\title{
Empowering Former Female Migrants in Sragen Indonesia
}

\author{
Ratih Rahmawati $^{1}$, Argyo Demartoto $^{2}$, RB Soemanto $^{3}$ \\ Postgraduate Sociology, Faculty of Social and Political Sciences, UniversitasSebelasMaret \\ Surakarta, Indonesia ${ }^{1}$ \\ Department of Sociology, Faculty of Social and Political Sciences, UniversitasSebelasMaret \\ Surakarta, Indonesia ${ }^{2,3}$ \\ \{ratih013@student.uns.ac.id ${ }^{1}$, argyodemartoto fisip@staff.uns.ac.id ${ }^{2}$, \\ rbsoemanto@yahoo.com ${ }^{3}$ \}
}

\begin{abstract}
Women, including the former female migrants, are vulnerable to enter into poverty circle. They need productive business to improve their family wellbeing. This research aims to analyze the empowerment of former female migrants in KAMI TKI Mukti Organization in Sragen Regency. Longwe's Gender analysis was used to analyze the enfranchisement of former female migrants with five techniques: wellbeing, access, participation, consciousness, and control. This qualitative research with case study approach processed the data in-depth and comprehensively through observation, interview, and documentation. The result of research showed that former female migrants have a productive activity such as cattle breeding, vegetable-processed food production, food catering, and net rope-made bag and wallet handicraft. The optimal income use can improve family wellbeing because the family's high motivation can save the remittance and can make it productive business capital. They have low consuming behavior and a strong desire to get out of the poverty circle.
\end{abstract}

Keywords: Former Female Migrant Empowerment

\section{Introduction}

The unemployment rate in Indonesia is high due to a limited job opportunity, but the number of productive age populations increases, so that the poverty rate increases as well. The gap insocial life can be dealt with community empowerment[1]-[3]. Every member of society contributes to improving economic and wellbeing levels, thereby competitive in getting a job. One alternative way to seek a job is to be migrant, as it is more promising than the same job at home, viewed from both wage and wellbeing security aspects[4]-[6]. However, behind that, there is some risk the female migrants should assume such as discriminative treatment. Majority female migrants work in the domestic sector such as household assistant, restaurant waitress, and baby sitter[7]-[9].

Government ensures the female migrants' safety to improve their standard of life. A new problem arises after the work contract of Indonesian workers has ended requiring them to go back to their origin area [10]-[12]. Former female migrants who come back into their origin area adapt difficulty to their new livelihood so that a reintegration process is needed to lead the former female migrants to undertake reasonable life in their origin area. Majority of former 
female migrants come back to their origin area to work in the farming sector and bring their habit during they were in a foreign country such as consumer behavior [13], [14], [15]. In line with Goal 5 of SDGs, Gender Equality and Women and Female Adolescent Empowerment, empowerment is required to raise degree, position, and role of women within society because in its development, there is a gap of role between men and women[16], [17]. It is relevant to Longwe's idea on empowerment and equality including in decision making[18]-[20].

Longwe's gender analysis is used to study women empowerment that wants to grow equality in development. The five criteria of Longwe's gender analysis are wellbeing, access, consciousness, participation, and control [18]. One of the organizations to provide job opportunity for former female migrants with productive business is KAMI TKI Mukti Organization in Mojorejo, Sragen, Indonesia. Former female migrants go back to their origin are not only relying on their remittance and using it up but also making it the capital for both joint (group) and independent businesses[21]-[23]. However, this situation is very difficult because there is a social construction about the role of women fettered with their nature (kodrat)developing in society. Gender is misinterpreted as it is defined as the nature (omnipotence), so that there is a stigma against the women. The phenomenon often occurring is that there is an awareness of the need for going toward the prosperous life, in which women participate in the development process and improve their life quality[24]-[26]. This research studied the Empowerment of Former Female Migrants in Sragen Indonesia.

\section{Literature review}

This research was taken place in KAMI TKI Mukti Organization Sragen, from January to May 2017. The subject of research was Manpower Service of Sragen Regency, administrators of Organization, former female migrants, family, and village apparatuses. The case study in this qualitative research explained the peculiarity and the typicality of former migrant empowerment. To validate data, method,and data source triangulation techniques were used. Techniques of analyzing data used were typology, description,and classification of data in detail according to its pattern to get meaningful data so that it can be analyzed and understandable to the readers [27].

\section{Result and discussion}

From the Summary of TKI placement in Manpower Service of Sragen Regency, it can be seen that Sragen becomes one of Regencies providing Indonesian Workers in Java Island annually and women dominate the number of citizens becoming the migrants as shown with the following data: 158 men (18.9\%) and 675 women $(81.1 \%)$ in 2014,252 men $(25.22 \%)$ and 747 women $(74.77 \%)$ in 2015,147 men $(16.7 \%)$ and 731 women $(83.2 \%)$ in 2016 , and 158 men (18.9\%) and 675 women (81.1\%) in 2017[28].

Majority productive-age populations in Mojorejo seek for a job abroad. Majority female migrants work in Hong Kong, Malaysia, Singapore and Taiwan [29]. To reduce the former female migrants' interest in returning to work again abroad, a productive business is neededto be the family's foothold without being migrants anymore. Data of former Indonesian workers for Mojorejo, Sragen Regency, in 2015, shows that 89 men (100\%) and 65 women $(27.31 \%)$ are still in productive age, and 173 women (72.68\%) are in unproductive age[30]. Out of 238 former female migrants, only 65 have a productive business, while the rests are only 
housewives. Overall, men dominate the ownership of business productive; thus, the majority of former female migrants do not have a productive business.

Former female migrants do not have a productive business due to high consuming behavior, low family motivation, and no strong desire to get out of the poverty circle. Some informants are having no productive business become housewives. When they come back to their origin area, their remittance is usually used to buy land and farm, to renovate the house, to buy a household appliance, to buy motor vehicle and jewelry. Thus, their income is used immediately, and they have no saving and no way of rotating income. Therefore, to suffice their life needs later, they resell the objects they have bought. Suyanti states that I did not use remittance for capital business purpose so that it has been used up all at once for paying children's tuition and building a house.

Former female migrants have inadequate family motivation, thereby having no wish to have a productive business. Children become the main reason. Although some of them follow activities in the Organization, they do not have a productive business because they should take care of their children fully. Ibu Parni (Mrs. Parni) stated that when going back to home (Indonesia), I just stay at home and take care of my children and husband. Those who come back to their origin area remain to be poor and disadvantaged because they have no strong desire to get out of poverty circle. Parni said that she is confused about what business she should have, as my children need more attention, and they do not allow me to go far away from them, so I can just be grateful for anything I have, my husband has income as he works as factory employees, despite inadequacy.

Keluarga Migran Tenaga Kerja Indonesia Mukti Organization (after that called Organization) has a general objective binding their members, that is, to realize the prosperous former female migrants of Mojorejo Village with both joint business and smalland mediumscale enterprises, and to empower and motivate the former female migrants to open small-and medium-scale enterprises. The activities include socialization, member recruitment, meeting and evaluation on a joint venture (cattle breeding) and smalland medium-scale enterprises (SMEs), local cultural preservation, service work training, business empowerment,and facilitation. The Manpower Service of Sragen Regency said that the productive activity conducted by former female migrants in the groupcould result in distinctive benefit and expand relation because silaturahim remains to be maintained with the fellow former migrants, either male or female. The Organization provides training to the former female migrants having no business and skill to keep developing and working independently. The business operated by former female migrants can minimize the loss resulting from the productive business because they can support each other for mutual success, different from the productive business conducted.

Sragen Government contributes to the empowerment of former female migrants by educating and training them through Manpower Service by means of socializing the Productive Migrant Village program, conducting a gathering to reinforce and to evaluate the migrant family community by Badan Nasional Penempatan dan Perlindungan Tenaga Kerja Indonesia (National Agency for Indonesian Worker Placement and Protection) of Central Java Province, and developing protection system for female migrants by Badan Kependudukan dan Keluarga Berencana Nasional (National Demography and Family Planning Agency) Women and Child Protection of Sragen Regency. This training activity can increase the former female migrants' knowledge, thereby improving their motivation to have independent, productive business to improve their family wellbeing.

The main productive activities of former female migrants are cattle breeding, vegetableprocessed food production, food catering, and net rope-made bag and wallet handicraft. Cattle 
breeding business conducted by former female migrants includes cricket breeding, goat breeding, chicken breeding, and cow breeding. Sugini, a cow breeder, said that attending the Organization and working in group benefits me much because more people will know me as a cow breeder. Thus in addition to the number of cows I have, the quality of my cows will be known, so that people will be interested and my cows will be sold out. Also, former female migrants have vegetable-processed food production business. As such, the local society's economy improves. Some others have food catering business for special events (hajatan). Similarly, through handicraft production business group producing bag and wallet, they produce the objects to be soled in tourist destinations, shops in urban areas, and even order from outside town or Java Island. Nanik Sukoco, the Secretary of Organization, stated that training the Organization provides a benefit not only the active members but also the wide society.

In practice, many former female migrants choose to live at home to be a housewife, taking care of husband and little children. It is this reason that cancels their intention to join the productive business. The profit resulting from the joint venture is too small so that it is considered as not fruitful and wasting time. Therefore, most of them prefer spending their time at home or working in the farming sector. Former female migrants have no productive business because they have no capital to buy material for business, for example for buying cattle and its feed, because their remittance has been used up. Non-entrepreneur migrants or those having no business do not want to take a risk by being an entrepreneur as they have under-five age children and consider that the income they get from entrepreneurship is small and it takes much their family time.

The less active former female migrants have poor awareness of activities in the Organization and productive activity. Meanwhile, the active former female migrants highly aware that women can operate a productive business and help improve the family economy without ignoring their duty and obligation. Nanik Sukoco stated that Mukti Organization has provided a variety of training and educations and has held a routine meeting once a month, but there are still former female migrants withdrawing from the organization, considering that the meetings are not too important and just wasting time. They prefer going to the farm to cultivate the land because of its clearer outcome.

The non-active former female migrants participate inadequately in decision making in Organizational meeting and feel that they have no right to freedom of expression. It can be seen from Dwi Rahayu, a vegetable vendor, saying that I just participate in the meetings because the decisions have been made and I am sure that it is intended for mutual benefit; lets other men deliver their suggestions. Women are only present at the meeting. The position and role of active and non-active former female workers do not contribute to the gap of capital mastery and to the opportunity of getting training and education from the Organization. Suparni, a counterfeit hair embroidery business performer, said that during attending the training and socialization of productive business by the organization, there is no discriminative treatment against men and women; some members do not attend the Organization activities usually because they are preoccupied with their household and farming affairs.

Considering the result of Longwe's gender analysis, it can be said that the family wellbeing level of former female migrants active in an organization improves because they are equipped with skill training and capital business. Thus, they have fixed income from productive business. The productive business operated by former female migrants can not only improve the wellbeing of members active in the productionprocess but also benefit the surrounding people so that the people's wellbeing improves as well [30]. However, those inactively attending the training and socialization in the Organization will find difficulty in 
embarking on business from both mental and capital aspects. To start a productive business, former female migrants attend education or training to equip themselves toknow how to get business capital and how to be an entrepreneur.

Former female migrants having a productive business is given freedom (access) by the family to be active in the Organization's activity, without ignoring their household obligation. The existence of successful former female migrants can benefit the surrounding people, in the term of health, education, income and even politics [18], [25], [26]. When former female migrants do not have freedom, after they have come back to their origin area, a regression has occurred.

\section{Conclusion}

Productive activity in Keluarga Migran Tenaga Kerja Indonesia Mukti Organization includes training and education on cattle breeding, vegetable-processed food production, food catering, and net rope-made bag and wallet handicraft businesses. In addition to increasing its members' income, it also increases their knowledge and skill. However, some members are inactive due to inadequate family motivation. Overall, the members of Organization, former female migrants, have an equal right to the males do in the term of training and capitalization, and business operated.

\section{References}

[1] E. Murphy-Graham, Opening Minds, Improving Lives: Education and Women's Empowerment in Honduras. Nashville: Vanderbilt University Press, 2012.

[2] H. Al-Dajani and S. Marlow, "Empowerment and entrepreneurship: a theoretical framework," Int. J. Entrep. Behav. Res., vol. 19, no. 5, pp. 503-524, 2013.

[3] K. McLaughlin, Empowerment: A Critique. Routledge, 2016.

[4] R. Germano, "Migrants' remittances and economic voting in the Mexican countryside," Elect. Stud., vol. 32, no. 4, pp. 875-885, 2013.

[5] I. . . . C. Mambula, "Characteristics of migrant entrepreneurs as agents of direct investment in sub-Saharan Africa: An observation of the Lebanese in Nigeria," World J. Entrep. Manag. Sustain. Dev., vol. 6, no. 3, pp. 193-212, 2010.

[6] E. Magnani and R. Zhu, "Gender wage differentials among rural-urban migrants in China,” Reg. Sci. Urban Econ., vol. 42, no. 5, pp. 779-793, 2012.

[7] A. Rydzik, A. Pritchard, N. Morgan, and D. Sedgley, "Humanising migrant women's work," Ann. Tour. Res., vol. 64, pp. 13-23, 2017.

[8] A. Waltz, "The women who feed us: Gender empowerment (or lack thereof) in rural Southern Brazilll,” J. Rural Stud., vol. 47, pp. 31-40, 2016.

[9] B. Zang, P. Lv, and C. M. J. Warren, "Housing prices, rural e urban migrants â€TM settlement decisions and their regional differences in China *," Habitat Int., vol. 50, pp. 149-159, 2015.

[10] K. Kuschminder, "Female Return Migration and Reintegration Strategies in Ethiopia," Maastricht University, 2013.

[11] A. Wilbur, "Back-to-the-house? Gender, domesticity and (dis)empowerment among back-to-the-land migrants in northern italy," J. Rural Stud., vol. 35, pp. 1-10, 2014.

[12] K. Wickramage, M. De Silva, and S. Peiris, "Patterns of abuse amongst Sri Lankan women returning home after working as domestic maids in the Middle East: An 
exploratory study of medico-legal referrals," J. Forensic Leg. Med., vol. 45, pp. 1-6, 2017.

[13] N. Hosoe, "Impact of border barriers, returning migrants, and trade diversion in Brexit: Firm exit and loss of variety," Econ. Model., vol. 69, 2017.

[14] H. Hanhörster and S. Weck, "Cross-local ties to migrant neighborhoods: The resource transfers of out-migrating Turkish middle-class households," Cities, vol. 59, pp. 193199, 2016.

[15] Kelik Wardiono; Wafda Vivid Izziyana, "Pekerja Imigran Perempuan dalam Perspektif Islam,” Istawa J. Pendidik. Islam, vol. 3, no. 2, pp. 1-24, 2018.

[16] T. Tufuor, A. Niehof, C. Sato, and H. van der Horst, "Extending the moral economy beyond households: Gendered livelihood strategies of single migrant women in Accra, Ghana," Women's Stud. Int. Forum, vol. 50, pp. 20-29, 2015.

[17] E. H. Naumburg and J. Hepworth, "Review of Feminist Family Therapy: Empowerment in Social Context," Fam. Syst. Heal., vol. 22, no. 1, pp. 127-129, 2004.

[18] C. March, I. Smyth, and M. Mukhopadhyay, A Guide to Gender- Analysis Frameworks. Oxford: Oxfarm GB, 2016.

[19] G. Allwood, "Gender mainstreaming and policy coherence for development: Unintended gender consequences and EU policy," Women's Stud. Int. Forum, vol. 39, pp. 42-52, 2013.

[20] K. Jenkins, "Women, mining and development: An emerging research agenda," Extr. Ind. Soc., vol. 1, no. 2, pp. 329-339, 2014.

[21] F. U. Beşpinar, "Questioning agency and empowerment: Women's work-related strategies and social class in urban Turkey," Women's Stud. Int. Forum, vol. 33, no. 6, pp. 523-532, 2010.

[22] B. J. Waddell and M. Fontenla, "The Mexican Dream? The effect of return migrants on hometown development," Soc. Sci. J., vol. 52, no. 3, pp. 386-396, 2015.

[23] S. Démurger and H. Xu, "Return Migrants: The Rise of New Entrepreneurs in Rural China," World Dev., vol. 39, no. 10, pp. 1847-1861, 2011.

[24] A. Christou and D. Michail, "Migrating motherhood and gendering exile: Eastern European women narrate migrancy and homing," Women's Stud. Int. Forum, vol. 52, pp. 71-81, 2015.

[25] X. Liu, L. Gao, J. Lu, and Y. Wei, "The role of highly skilled migrants in the process of inter-firm knowledge transfer across borders," J. World Bus., vol. 50, no. 1, pp. 5668, 2015.

[26] F. Hu, "Return to Education for China's Return Migrant Entrepreneurs," World Dev., vol. 72, p. 296-307.264-267., 2015.

[27] M. Patton, Qualitative Evaluation and Research Methods. Thousand Oaks: Sage Publications, Inc., 1990.

[28] "Summary of Indonesia Migrant Worker Placement in Manpower Service of Sragen Regency." .

[29] "Data of TKI Destination from Manpower Service of Sragen Regency." 2016.

[30] "Profile of KAMI TKI MUKTI Organization in Mojorejo Village, Karangmalang Sub District, Sragen Regency." . 